\title{
Regulating Pet Insurance in Indonesia
}

\author{
Ermanto Fahamsyah \\ University of Jember, Indonesia \\ ermanto_fahamsyah@yahoo.co.id \\ Iswi Hariyani \\ University of Jember, Indonesia \\ iswihariyanil@gmail.com
}

\author{
Ance Rimba \\ University of Jember, Indonesia \\ ance.rimba@gmail.com
}

\begin{abstract}
Nowadays Indonesia has not had a regulation on pet insurance. Meanwhile, in practice, there already are some pet insurance products. This gap has led to pet insurance policies that are only being based on general contract regulations and principles. One of the general contract principles is the consensual principle which is outlined in Article 1320 paragraph 1 of the Civil Code. The research of this paper is conducted based on pet insurance regulations, principles and norms application. It concludes that pet insurance policies that are being based only on the consensual principle have binding legal force as regulated on Article 1338 of the Civil Code. The conception of pet insurance in Indonesia subsequently should refer to the Ministerial Regulations, such as the Regulation of Minister of Agriculture Number 40/Permentan/SR.230/7/2015 regarding Agriculture Insurance Facility and also other supplementary regulations.
\end{abstract}

KEYWORDS: Pet Insurance, Insurance Law, Insurance Contracts.

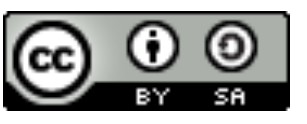

Copyright $\odot 2020$ by Author(s)

This work is licensed under a Creative Commons Attribution-ShareAlike 4.0 International License. All writings published in this journal are personal views of the authors and do not represent the views of this journal and the author's affiliated institutions.

\section{HOW TO CITE:}

Fahamsyah, Ermanto, Iswi Hariyani \& Ance Rimba. "Regulating Pet Insurance in Indonesia" (2020) 7:1 Lentera Hukum 55-68.

Submitted: July 20, 2019 Revised: December 05, 2019 Accepted: December 17, 2019 


\section{INTRODUCTION}

Nowadays, insurance has become part of the daily lifestyle for millennials. The need for insurance derives from the awareness of the risks that can occur at any time while people are carrying out daily activities. In Indonesia, these risks can take the form of losses, damage to property, costs incurred, loss of profits, legal liability, disability, and even death. These losses must be covered for people, which is the responsibility of insurance companies. ${ }^{1}$ As the demands of the age begin to emerge, new types of insurance are expected and deserved by the people: lifestyle insurance, pet insurance, body parts insurance, music protection insurance, and flight delay insurance, among others.

In national pet insurance is commonly known by people. Moreover, some countries already have regulations in place regarding the protection of animals, both generally and pets. For example, Japan has the Act on Welfare and Management of Animals. ${ }^{2}$ This regulation regulates the treatment of animals, explicitly prohibiting injure and torture, and stating the obligation for proper treatment and a suitable living place. As another example, Singapore has The Animals and Birds Act, ${ }^{3}$ which regulates the obligations of pet owners as the following: vaccinating their pets against rabies, limiting ownership to three dogs unless prior approval from the Director-General of the Agri-Food \& Veterinary Authority of Singapore (AVA) is obtained, among other regulations.

Regulations that govern pet ownership encourage owners to take responsibility for the welfare of their animals. One way to ensure responsibility is through pet insurance. At present, are no regulations that specifically regulate pet insurance in Indonesia. Still, in practice, pet insurance has been carried out, so pet insurance agreements without specific rules only based on general rules and principles of the deal, one of which is the principle of consensus as stated in Article 1320 paragraph (1) of the Civil Code whereas one of the conditions for the legality of the agreement is the agreement of both parties.

This paper contains three research problems. First, it discusses whether pet insurance agreements based on the principle of consensual that have the legal force for which it aims to analyze the legal power of pet insurance agreements that are based solely on the Principle of Consensus. Second, this paper analyzes pet insurance arrangements in other countries to compare them to current and potential regulations in Indonesia. Third, this paper analyzes future conceptions of pet insurance arrangements in Indonesia based on all collected information.

This paper uses legal research. In this research, a literature review was conducted to identify legal facts, collect legal and non-legal materials, and examine legal issues raised based on the elements that have received. This goal for this process was to and provided prescriptions based on policies in the form of conclusions. The approach used to analyze all collected information was the statutory approach, conceptual approach,

1 Emmy Pangaribuan Simanjuntak, Commercial Law Section (Yogyakarta: Insurance Law, 1990) at 5.

2 World Animal Protection Organization, Japan Animal Protection Profile, (2015) online: 〈https://api.worldanimalprotection.org/country/japan〉

3 Perro Pet, Laws About Owning Pets in Singapore (2018), online: 〈https://www.perropet.com/ 2017/09/19/ laws-owning-pets-singapores. 
and comparative approach. The legal materials used were primary legal materials, secondary legal materials, and non-legal materials.

\section{EXAMINING LEGAL INSURANCE CONTRACTS SOLELY BASED ONLY ON CONSENSUALISM}

Contract as one source of disagreement is defined in Article 1313 of the Civil Code as follows: "Agreement is an act by which one or more people commit themselves to one or more other people." There are several principles in contract ${ }^{4}$ law, which includes the principle of freedom of contract, the principle of consensual, the principle of pacta sunt servanda, the principle of personality, and the principle of good faith. An agreement which follows the principle of freedom of contract is one that has fulfilled the legal requirements of the deal as stipulated in article 1320 of the Civil Code and also does not violate public order and morality ${ }^{5}$.One such type of agreement is an insurance agreement. An insurance agreement is a type of nameless agreement (innominate), which arises, grows, lives, and develops in society according to .... [what makes it grow/live/develop? Public opinion? Please state the impetus for the dynamism of insurance agreements]. ${ }^{6}$ In Indonesia, insurance agreements are stipulated in Article 1319 of the Civil Code, which is generally regulated in book III of the Civil Code, and explicated again in section 246 of the Indonesian Criminal Code and Law Number 40 of 2014 concerning Insurance.

In Indonesia, insurance arrangements generally only cover loss, damage, costs incurred, loss of profits, legal liability, and life insurance based on the death of the insured. It is stated in Article 1, number 1 of Law Number 40 of 2014 concerning Insurance. In contrast to other types of insurance that have already become popular, Indonesia still does not have special regulations governing pet insurance. A pet insurance agreement is a type of nameless agreement (innominate), whose definition did not exist during the development of the third book of the Civil Code. Therefore, it has arrangements outside of the Civil Code. ${ }^{7}$ Because this insurance has not yet been regulated in a specific regulation, insurance agreements related to pet insurance are based solely on the principle of consensual understanding.

Insurance agreements fall within the category of Treaty Law, which adheres to an open system in order to give participants the broadest possible freedom for entering into agreements of any type, so long as the deal does not violate public order and decency. ${ }^{8}$ For the transaction to be valid and binding, the agreement must fulfill the legal conditions of the contract as stipulated in article 1320 of the Civil Code.

4 Salim H.S., Contract Law, Theory, and Engineering of Contract Preparation (Jakarta: Sinar Grafika, 2008) at 22.

5 R. Subekti, Law of Agreement (Jakarta: Intermasa, 2009) at 13.

6 Salim H.S., supra note 4 at 47.

7 Ibid.

8 R. Subekti, supra note 5. 
The principle of freedom of contract contained in article 1338 paragraph (1) of the Civil Code states that: "all treaties made legally apply as a law for those who make them." This principle is a principle that gives freedom to the parties to': first, to make or not agree; second, to possess the freedom to enter into agreements with anyone; third, to determine the contents of the agreement, particularly regarding its implementation and terms; and fourth, to determine the form of the agreement (written or oral).

A pet insurance agreement is valid and binding so long as the agreement meets the legal conditions of the agreement in article 1320 of the Civil Code and does not violate public order and decency. This validity does not rule out the possibility that agreements may be one-sided and disproportionate, such that they are more beneficial for one party and detrimental to the other.

Anindya Nugrahani Kusumoardi stated that: ${ }^{10}$

"Insurance companies increase efficiency by providing insurance agreements that contain an agreement between the insurer (insurance company) and the insured party on a risk to be insured and the amount of premium to be paid in exchange for the coverage. This insurance agreement is usually called a policy, which contains standard clauses therein. "

Article 10, number 10 of Law Number 8 of 1999 concerning Consumer Protection defines the standard clause as follows:

"Standard clauses are any rules or conditions and conditions prepared by business actors as outlined in a document and/or agreement that is binding and must be fulfilled by consumers."

A standard agreement is one whose contents have been standardized by a robust economic party while the other parties are only asked to accept or reject the materials." If the insured party accepts the contents of the agreement the signs the agreement, if the insured party refuses the contents of the agreement, then he does not endorse the agreement, and the agreement deemed non-existent. The standard agreement in pet insurance is not against the law. Often the "position" of the parties becomes unbalanced, which gives rise to contracts that only benefit one party. For example, in some cases, the implementation of standard clauses removes the ability of the insured to negotiate. As a result, the agreement can be one-sided. ${ }^{12}$ It is not uncommon for the insured to be strategically placed in a weak position by the opposing party so that bargaining power resides in the hands of the insurance company. In these cases, insurers have ample opportunity to determine the contents of the agreement, though the same does not apply to the insured.

Pet insurance has not regulated explicitly through positive law in Indonesia. It creates a legal vacuum in the field of insurance law, especially that of pet insurance. The legal space in the area of pet insurance can create inconsistencies in the pet insurance

9 Salim H.S., supra note 4 at 9.

10 Anindya Nugrahani Kusumoardi, Raw Clause in the Fire Insurance Policy Judging from Law Number 8 of 1999 Concerning Consumer Protection (Case Study at PT Asuransi Jasa Indonesia), (2016) 5:3 Diponegoro Law Journal, at 3.

11 Salim HS, Development of Contract Law outside the Civil Code (Jakarta: PT Rajagrafindo Persada, 2016) at 147.

12 Anindya Nugrahani Kusumoardi, supra note 10. 
agreements used by one insurance company and the pet insurance agreement of another insurance company. As a result, there are no standard regulations regarding what things must be clarified or prohibited in the agreement, pet species coverage, categories for protection, and insurance premium costs, as just a few examples. The position of the guarantor as the maker of a standard pet insurance agreement becomes very dominant because there are no specific restrictions that they must obey through the agreement. At the same time, the location of the insured is not so dominant because the insurer entirely makes the standard insurance agreement, and not all insured understands the absence of special regulations governing pet insurance.

\section{PET INSURANCE IN OTHER COUNTRIES}

Pet insurance arrangements are a binding order which regulates the public in making and implementing a risk transfer agreement on objects in the form of pets that may occur from the insured party that is the insurance policyholder, which can be a legal entity or an individual to the insurer namely the insurance company. Regulations provide rules for what must be done and what should not be done by involved parties. Each country has regulations on pet insurance that vary or differ from one another.

\section{A. Pet Insurance Arrangements in Japan}

Japanese society began shifting from initially assuming that pets are only animals to assuming that pets are family members in the 1980s. ${ }^{13}$ Accompanying this shift is the phenomenon that more and more Japanese people own pets. The pet boom phenomenon occurred in full force in 1996. ${ }^{14}$ Pets function as friends of their owners as well as status symbols. The pet boom trend opened up opportunities in the business world relating to money-making endeavors, like pet spas, pet hotels, pet clothes, pet cafes, and pet insurance.

In general, insurance companies in Japan fall into one of two categories: Life Insurance and Non-Life Insurance. All insurance companies in Japan must have a license from the Prime Minister to be able to do business. One insurance company may not possess permissions for both types of insurances at the same time (Life Insurance and Non-Life Insurance. $)^{15}$ Pet insurance is classified as Non-Life Insurance, according to Article 3 paragraph (1), (2), and (3) Insurance Business Act (Act No. 105 of June 7, 1995).

A Life Insurance Company is a company with a license to run an insurance business related to the coverage of unity, death or life of a person (including someone who has been diagnosed with a fatal disease by a doctor); certain diseases that affect a person such as an injury or illness suffered by a person which cause specific conditions (for example, disabilities); the death of a person due to injury; or cases and other treatments as

13 Anita Sawitri Dradjat, Thesis: "The Linkage between Loneliness in the Elderly in the Old Age with Pet Booms in Japan" (Depok: University of Indonesia, 2010) at 2

14 Ibid.

15 Shared Research Inc., Anicom Holdings Research Coverage (Tokyo: Shared Research Inc, 2016) at 3. 
determined by the Office Cabinet Ordinance. These stipulations are under Article 3 paragraph (4).

In Japan, there are three main types of Life Insurance: death insurance, dualpurpose insurance, and health and accident insurance. ${ }^{16}$ Death insurance is insurance that provides coverage for the death of the insured. Dual-use insurance covers the insured. Health and accident insurance covers treatments related to sickness, certain conditions such as disabilities, and accidents for the insured.

A Non-Life Insurance Company is a company with a license to carry out insurance business related to coverage of damage caused by accidents; certain diseases; injuries or illness suffered which cause particular conditions; death due to injury; cases and other treatments as determined by the Office Cabinet Ordinance; and death while traveling abroad. These are under Article 3 paragraph (5) sections (i), (ii) and (iii).

Japan still regards animals as objects and has not explicitly regulated pet insurance. Japan sought to reconcile this by establishing the Welfare and Management of Animals Act (Act No. 105 of October 1, 1973), which guarantees animal welfare and regulates the treatment of animals.

The Welfare and Management of Animals Act (Act No. 105 of October 1, 1973) prohibits the destruction, injury, or and torture of animals. Additionally, it requires owners? Citizens? to treat animals properly through Article 2 paragraph (1):

"In light of the fact that animals are living beings, no person shall destroy, injure, or inflict cruelty on animals without reason, and every person shall treat animals properly by taking into account their natural habits and giving consideration to the symbiosis between humans and animals."

Every prefecture in Japan is required to develop an animal welfare and management promotion plan which consists of the following: basic rules that ensure good animal welfare and management; stipulations regarding the care and medical treatment for animals; rules for caring for animals in the case of disasters; and matters relating to the work program which is responsible for implementing good animal welfare (such as establishing cooperation between the central government, regional governments, and private institutions). The rules for animal welfare and management promotion plans are defined in Article 6, paragraph (1), and (2).

All pet owners are obliged to provide proper management and well-being for their pets. They are responsible for caring for the health of their animals, including the safety of the animal. Additionally, they must ensure that their pets do not cause damage to other people's property or pose hazards or problems for others in the environment. To do this, they must collect appropriate information about infectious diseases that can infect their pets and also prevent their pets from contracting the illness. They must take the necessary steps so that their animals do not run away, prevent their pets from breeding freely, and follow established procedures for adopting a pet and be able to prove its ownership of the pet. It refers to Article 7.

16 Taiyo and Daido Holdings, T\&D Annual Report 2018 (Tokyo: T\&D Holdings, 2018) at 71. 
Pet insurance in Japan is included in the Non-Life Insurance type of insurance. It is generally regulated in the Insurance Business Act (Act No. 105 of June 7, 1995, with its supporting rules, namely Welfare and Management of Animals Act (Act No. 105 of October 1, 1973). The existence of the Welfare and Management of Animals Act requires animal owners to care for their pets properly. It often leads to many pet owners insuring their pets.

\section{B. Pet Insurance Arrangements in France}

The French state divides insurance into two general categories, namely Life Insurance and Non-Life Insurance. ${ }^{17}$ All forms of insurance business in France are generally regulated in the Code des Insurance (Insurance Code). All insurance companies must have a license from the Autorité de Contrôle Prudentiel et de Résolution (ACPR) (The French Supervisory Authority) to be able to run their business. One insurance company cannot possess two licenses (Life Insurance and Non-Life Insurance) simultaneously. ${ }^{18}$

Pet insurance in France classified as Non-Life Insurance. ${ }^{19}$ Pets must be registered with the local veterinarian before they can be insured..$^{20}$ Registered pets will be given a tattoo or chip as an identifier. ${ }^{21}$ Pet insurance in France is usually combined with multirisk insurance for a residence (home). ${ }^{22}$ If a pet is not insured, the owner is still required to at least take responsibility for legal liability insurance for ${ }^{23}$ the pet.

France does not manage pet health insurance through topic-specific regulations, but many other laws exist to guarantee animal welfare and to monitor the treatment of animals. France was one of the first countries to establish legislation regarding animal protection and health. The first French legislative regulation on animal protection was the Grammont Law. This law promulgated on July 2, 1850, ${ }^{24}$ states that: "those who have abusively maltreated domestic animals will be punished by a 5 to 15 fine francs fine, and could face a 5-day jail sentence."

The limitations of the Grammont Law to domestic animals were extended through Decree No. 59-1051, which applied the Grammont Law to non-domestic animals as well as

17 London Economics, Study on Consumers' Decision Making in Insurance Services: A Behavioural Economics Perspective - Final Report - Country Fiches (Brussels: Directorate-General for Justice and Consumers Unit 0.3 European Commission, 2017) at 8.

18 The In-House Lawyer, Is Authorisation or A Licence Required and If So, How Long Does It Take on Average to Obtain Such Permission? (2018), online: 〈https:/www.inhouselawyer.co.uk/wgd_ question/is-authorisation-or-a-licence-required-and-if-so-how-long-does-it-take-on-average-toobtain-such-permission/>

19 Crédit Agricole Britline, Pet Insurance for Cats and Dogs (2019), online: < https:/www.britline.com/insurance-cats-dogs.html>

20 CL\&EP Assurances, Pet Insurance (2019), online: 〈https://www.clp-assurances.fr/en/personal/ insurance/pet-insurance>

21 Ibid.

22 Ibid.

23 Ibid.

24 Loïs Laimene Lelanchon, Detailed Discussion of Anti-maltreatment Laws in France and Spain, (2013), online: 〈https://www.animallaw.info/article/detailde-discussion-anti-maltreatment-laws-france-andspain/> 
domestic. ${ }^{25}$ On 19 November 1963, Law 63-1143 on Animal Protection replaced the Grammont Law. The Law 63-1143 added to the term maltreatments (such as improper or inadequate treatment) with acts of cruelty. ${ }^{26}$ In 1976, Law 63-1143 was replaced by The Law 76-629 on Nature Protection. Law 76-629 protects animals, including livestock, domestic pets, laboratory animals, and captured wild animals. ${ }^{27}$ Law 76-629 has recognized animals as living things, not just objects, as in the France Civil Code. ${ }^{28}$ This definition creates a vital overlap in French legislation. The Law 76-629 is still valid today. ${ }^{29}$

On 1 June 1999, France enacted special legislation governing dogs, which were previously?not allowed, or only allowed with special conditions, to enter the country. ${ }^{30}$ This regulation is known as The Law 99-5 or The Dangerous and Stray Animals Law (The Dangerous Dog Law). ${ }^{31}$ In 2009 27, the Agriculture Ministers at the European Council, including France, received the Universal Declaration on Animal Welfare (UDAW) declaration, which supported the movement to raise awareness and create a more significant international consensus on animal welfare. ${ }^{32}$ In 2013, lawmakers in the France National Assembly Legal Committee held a vote to change the legal status of animals in the France Civil Code. The voting results state that the condition of animals in the France Civil Code changed from "things" to "living things ${ }^{33}$

Pet insurance in France is included in the Non-Life Insurance type of Insurance, which usually combined with multi-risk residence insurance (home). Non-Life Insurance is generally regulated in Code des Insurance (Insurance Code) and has several supporting rules such as the Law 76-629 on Nature Protection and The Law 99-5 or The Dangerous and Stray Animals Law (The Dangerous Dog Law). It would strengthen this section to include a sentence that summarizes the importance of the information collected about France.

25 Ibid.

26 Ibid.

27 World Animal Protection Organization, France Animal Protection Profile, (2015), online: 〈https://api.worldanimal protection.org/country/france〉

28 Loïs Laimene Lelanchon, supra note 24.

29 Ibid.

30 Ministère de L'agriculture et de L'alimentation, Circulations Transfrontaliere Tableau Recapitulatif Chiens Dangereux in English, (2018), online: 〈https:/www.agriculture.gouv.fr/file /circulationsfrontaliere-tableaurecapitulatifchiensdangereux-englishcle03bf3epdf>

31 Brenda Bonnett, The French Situation: Dangerous Dogs, (2015), online: 〈https://www.dogwellnet.com/content/welfare-legislation/dog-specific-legislation/dangerous-doglegislation/the-french-situation-danger ous-dogs-rl88/>

32 World Animal Protection Organization, supra note 27.

33." Joshua Melvin, Pets to No Longer Be Seen As Just 'Chairs' in France, (2014), online: 〈https://www.thelocal.fr/20140416/animals-to-no-longer-be-furniture-in-france/amp〉 


\section{THE CONCEPT OF PRIVATE CONCERNING ARRANGEMENTS OF PET INSURANCE IN INDONESIA}

A. The Current Pet Insurance Policies in Indonesia

There is no specific regulation governing pet insurance in Indonesia. Besides that, the Civil Code in Indonesia also still considers animals as moving objects rather than as living things. ${ }^{34}$ It is because the Indonesian Civil Code adopted the Dutch Burgerlijk Wetboek $^{35}$ from the French Code Napoleon (Code Civil des Français). ${ }^{36}$ Code Napoleon (Code Civil des Français) comes from Roman law. ${ }^{37}$ The three regulations sourced from the Civil Code see animals as moving objects. ${ }^{38}$ Unlike European countries such as France and Spain, which have renewed their Civil Code, ${ }^{39}$ Indonesia still uses the Civil Code, which adopts the Burgerlijk Wetboek Netherlands. ${ }^{40}$ In this Code, animals are still regarded as moving objects rather than living things, resulting in the limited rights and protections of animals (including pets). ${ }^{41}$

There are several regulations in positive law regarding animals (including pets), which can be used as a starting point to form specific regulations regarding pet insurance. The first of which is Article 1368 of the Civil Code, which requires a pet owner to fulfill obligations and take full responsibility for losses incurred by his pet. ${ }^{42}$ One of these losses can also be an infectious disease that can be transmitted by these pets to other animals and humans. Another of which is Law Number 16 of 1992 concerning the quarantining of animals and plants, which was formed due to the state's concern for animal, fish and plant health. This law requires owners of animals and plants to have health certificates and receive regular health checks. Animal quarantine is not the obligation of only one party or country but also the obligation of the community. Another relevant law is Law Number 41 Year 2014 Regarding Amendments to Law Number 18 Year 2009 Concerning Animal Husbandry and Health. It is a tangible way through which the government has taken action to protect animals by obliging citizens to take care, shelter, care, and protect animals as well as possible ${ }^{43}$ so that animals can be free from hunger and thirst, pain, abuse, and abuse.

Indonesia does not have particular regulations regarding pet insurance. Some insurance which has been specifically regulated include: ${ }^{44}$ Motor Vehicle Insurance which is regulated in the Minister of Finance Regulation Number 74/PMK.010/2007 which is then amended by Regulation of the Minister of Finance Number

34 Ibid.

35 Fence M. Wantu, Introduction to Legal Studies, (Gorontalo: UNG Press, 2015) at 41

36 Wirjono Prodjodikoro, Civil Law Principles (Bandung: Bandung Well, 1983) at 9

37 Ibid.

38 Ibid.

39 Loïs Laimene Lelanchon, supra note 24.

40 Ibid.

41 Subekti, supra note 5 at 10.

42 Fence M. Wantu, supra note 35.

43 Munir Fuady I., Comparison of Civil Law (Bandung: Citra Aditya Bakti, 2015) at 144.

44 Tri Jata Ayu Pramesti, Animal Liability Legal Responsibilities (2016), online: 〈https://www.hukumonline.com/klinik/detail/lt56e3ac03eel57/animallegalresponsibilities-/\#_ftn2〉 
01/PMK.010/2011 concerning the Implementation of Insurance Coverage for Insurance Business Lines Motor vehicle; Credit and Suretyship Insurance regulated in Minister of Finance Regulation Number 124/PMK.010/2008 concerning Operation of Credit and Suretyship Business Lines; Indonesian Workers' Insurance which is regulated in Minister of Manpower and Transmigration Regulation Number PER.07/MEN/V/2010 which is then amended by Minister of Manpower and Transmigration Regulation No. 1 of 2012 concerning Indonesian Workers Insurance; and Agricultural Insurance as stipulated in the Regulation of the Minister of Agriculture of the Republic of Indonesia Number 40/Permentan/SR.230/7/2015 on Agricultural Insurance Facilities and others.

\section{B. Pet Insurance Arrangements in Indonesia}

Specific regulations governing pet insurance are needed so that guidelines may be developed regarding things which must be stated in agreements, things that are prohibited, what pets are covered, categories for insurance coverage, and rates for pet insurance premiums. This particular regulation is needed so that the position between the guarantor (insurance company) and the insured may become more proportional.

Disproportionality in pet insurance agreements can arise from ${ }^{45}$ insurance agreements made in haste, with only company efficiency in mind that contain an agreement between the insurer (insurance company) and the insured party. This insurance agreement is usually called a policy, which contains standard clauses therein.

Generally, standard agreements in pet insurance do not conflict with the law. However, often the "position" of the parties becomes unbalanced, resulting in contracts that only benefit one party. The application of the standard clause results in the loss of the ability of the insured to negotiate the terms of the agreement. ${ }^{46}$ It is not uncommon that the insured is forced into a weak position during bargaining due to differences in status. Insurers have ample opportunity to determine the contents of the agreement while the same does not apply to the insured party.

Specific regulations regarding pet insurance can take the form of ministerial laws in addition to Regulation of the Minister of Agriculture of the Republic of Indonesia Number 40/Permentan/SR.230/7/2015 concerning Agricultural Insurance Facilities. In addition to ministerial regulations, supporting regulations are needed, namely regulations on animal welfare, regulations on animals that prohibited from entering Indonesia (similar to the Dangerous Dog Law), and regulations that require pet owners to register their pets. These changes may be marked by provision for tattoos or chips on animals, as well as other laws and regulations that are felt necessary by lawmakers. Changes to regulation, such as the ones listed above, are essential in rebalancing the relationship between insurance companies and those insured.

45 Letezia Tobing, Hukum, Body Member Insurance in Indonesia, (2015), online: 〈https://www.hukumonline.com/klinik/detail/lt560aa0c375534/insurance-member-body-inindonesia- $/>$

46 Anindya Nugrahani Kusumoardi, supra note 10. 
Regulations regarding animal welfare, such as The France Law 76-629 on Nature Protection and the Japan Welfare and Management of Animals Act (Act No. 105 of October 1, 1973), are essential because they provide more protection to animals in general than previously existed. Regulations regarding animal welfare can prevent the mistreatment of animals. Through this regulation, Indonesia can take further steps in the field of animal law by updating the status of animals from objects to living things. Rules prohibiting the entry of animals into the country, similar to the France Law 99-5 or The Dangerous and Stray Animals Law (the Dangerous Dog Law), would help with the regulation of dogs or animals. ${ }^{47}$ This regulation is significant because naturally, there are some animals whose natural behavior is more aggressive than other animals. This regulation can reduce the risk that an animal can damage property or hurt someone.

Additionally, this regulation can also help insurance companies determine whether the company will accept insurance for animals that are included in the category of Dangerous Animals (especially dogs) or not. ${ }^{48}$ Insurance companies that accept animal insurance in the category of Dangerous Animals charge a more expensive premium for them. Regulations requiring pet owners to register their pets through marking with tattoos or chips in animals are contained within the Jakarta Governor Regulation No. 199 of 2016 concerning Controlling Animal Rabies. These regulations are essential in the effort to control animal populations, facilitate the search for lost animals, and record a history of animal diseases and a history of vaccinations. In addition to ministerial regulations or other regulations that provide a legal umbrella for the parties in pet insurance and supporting regulations, lawmakers can also form other regulations to provide more legal protection for the parties involved in pet insurance.

The formation of legislation takes a long time. It means that the existing legal vacuum cannot be filled immediately. It is in part due to the process of lawmaking. Before laws and regulations can be formed, academic texts must be established so that they can use as material for making laws and regulations. ${ }^{49}$ The academic manuscript formation is carried out by academics ${ }^{50}$ and requires time in its preparation because it qualified research must be conducted. Before special legislation regarding pet insurance can be formed, a Financial Services Authority Regulation on pet insurance must be established. The Financial Services Authority has the authority to create regulations regarding pet insurance because of its function as stipulated in Article 5 of Law Number 21 of the Year 2011 concerning the Financial Services Authority: "OJK has the purpose of organizing an integrated regulation and supervision system for all activities in the financial services sector." This authority is contained in Article 8 of Law Number 21 of the Year 2011 concerning the Financial Services Authority.

47 Ibid.

48 Ministère de L'agriculture et de L'alimentation, supra note 30.

49 Jason D Cass, Dog Breeds Your Insurance Company Doesn't Like, (2017), online: 〈https://www.theinsurancealliance.com/10-dog-breeds-your-insurance-company-doesnt-like/〉

50 Abdul Basyir, The Importance of Academic Texts in the Formation of Legislation to Realize Aspirational and Responsive Laws, (2014) 2:5 IUS Journal Law and Justice Study at 291. 
Additionally, a pet insurance standard policy must be established by the Indonesian General Insurance Association (AAUI). A standard procedure ${ }^{51}$ provides a reference for stipulations to include in specific insurance policies in Indonesia. ${ }^{52}$ The existence of the Financial Services Authority regulations and pet insurance standard policies can provide reference legislation that explicitly regulates pet insurance. Financial Services Authority regulations and pet insurance standard policies can minimize the imbalance between the guarantor (insurance company) and the insured. In order to fill the vacancy of a pet insurance arrangement, a statutory regulation must be formed at the same level as a Ministerial Regulation. In addition to establishing laws and regulations, lawmakers can also develop other rules that can complement the Ministerial Regulation on pet insurance. That being said, forming a statutory provision requires a significant amount of time. To fill the current regulatory vacuum, a Financial Services Authority or AAUI standard policy can be created.

\section{CONCLUSION}

Pet insurance agreements have legal force if they have fulfilled the legal requirements of the transaction as stipulated in article 1320 of the Civil Code and if they do not conflict with public order and decency. It is following the principle of freedom of contract specified in Article 1338 of the Civil Code. Pet insurance arrangements are not explicitly regulated in countries such as Japan and France. Japan regulates pet insurance in general through the Business Insurance Act (Act No. 105 of June 7, 1995) as Non-Life Insurance with its supporting rules, namely the Welfare and Management of Animals Act (Act No. 105 of October 1, 1973). France regulates pet insurance in general in the Code des Insurance (Insurance Code) as Non-Life Insurance with its supporting rules, namely The Law 76-629 on Nature Protection and The Law 99-5 or the Dangerous and Stray Animals Law (the Dangerous Dog Law). At present, Indonesia does not yet have specific rules governing pet insurance. Future conceptions regarding the regulation of pet insurance in Indonesia should form specific regulations regarding pet insurance in the form of ministerial regulations.

\section{ACKNOWLEDGMENTS}

None.

\section{COMPETING INTERESTS}

The authors declare that they have no competing interests.

51 Ibid.

52 Ilham Ahmad, This is the Definition of Insurance Policies Unknown to Many People, (2018), online: 〈https://www.cekpremi.com/blog/peng-polis-as Asuransi-yang-belum-d unknown-banyak-people/〉 


\section{REFERENCES}

Abdul Basyir. The Importance of Academic Manuscripts in the Formation of Legislation to Realize Aspirational and Responsive Laws. (2014) 2:5 IUS Journal: Law and Justice Study.

Anindya Nugrahani Kusumoardi. Standard clause in the fire insurance policy in terms of Act No. 8 of 1999 concerning Consumer Protection (Case Study at PT Asuransi Jasa Indonesia). (2016) 5:3 Diponegoro Law Journal.

Anita Sawitri Dradjat. Thesis: "The Link Between Loneliness in Old Age Elderly and Pet Booms in Japan," (Depok: University of Indonesia, 2010).

Brenda Bonnett, "The French Situation: Dangerous Dogs", (2015) online: DogWellNet IPFD 〈https:/www.dogwellnet.com/content/welfare-legislation/dog-specific-legi slation/dangerous-dog-legislation/the-french-situation-danger ous-dogs-rl88/>

CL\&P Assurances, "Pet Insurance" (2019) online: clp-assurances 〈https://www.clp-assurances.fr/en/personal/insurance/pet-insurance〉

Crédit Agricole Britline, "Pet Insurance for Cats and Dogs", (2019) online: britline.com 〈https://www.britline.com/insurance-cats-dogs.html〉

Emmy Pangaribuan Simanjuntak. Coverage Law, (Yogyakarta: Commercial Law Section, 1990) Faculty of Law, Gadjah Mada University.

Fence M. Wantu. Introduction to Law. (Gorontalo: UNG Press, 2015).

Indonesian General Insurance Association, "Vision and Mission of the Indonesian General Insurance Association” (2018) online: AAUI 〈https://aaui.or.id/visimisi/ $\$ 1527746515273-28234300-f 048>$

Ilham Ahmad, "This Is the Understanding of the Unknown to Many People's Insurance Policy" (2018) online: Premium Check 〈https:/www.cekpremi.com/blog/ pengertian-polis-asuransi-yang-belum-diketahui-banyak-orang/>

Jason D Cass, "10 Dog Breeds Your Insurance Company Doesn't Like” (2017) online: The Insurance Alliance 〈https://www.theinsurancealliance.com/10-dog-breeds-yourinsurance-company-doesnt-like/>

Joshua Melvin, Pets to No Longer Be Seen As Just 'Chairs' in France” (2014) online: The Local 〈https:/www.thelocal.fr/20140416/animals-to-no-longer-be-furniture-infrance/amp>

Letezia Tobing, "Member Body Insurance in Indonesia" (2015) online: hukumonline.com 〈https://www.hukumonline.com/klinik/detail/lt560aa0c375534/asuransi-anggota -tubuh-di-indonesia-/>

Loïs Laimene Lelanchon, "Detailed Discussion of Anti-maltreatment Laws in France and Spain" (2013) online: Animal Law <https://www.animallaw.info/article/ detaildediscussion-anti-maltreatment-laws-france-and-spain \#top〉

London Economics. Study on Consumers' Decision Making in Insurance Services: A Behavioural Economics Perspective - Final Report - Country Fiches. (Brussels: Directorate-General for Justice and Consumers Unit 0.3 European Commission, 2017)

Ministère de L'agriculture et de L'alimentation, "Circulations Transfrontaliere Tableau Recapitulatif Chiens Dangereux in English" (2018) online: Alim'agri 
〈https://www.agriculture.gouv.fr/file/circulationsfrontalieretableaurecapitulatifchiens dangereux-englishcle03bf3epdf $>$

Munir Fuady I. Perbandingan Hukum Perdata. (Bandung: Citra Aditya Bakti, 2015)

Perro Pet, "Laws About Owning Pets in Singapore" (2017) online: perropet.com 〈https://www.perropet.com/2017/09/19/laws-owning-pets-singapore〉

R. Subekti. Legal Agreement. (Jakarta: Intermasa, 2009)

Salim HS. Development of Contract Law outside the Civil Code. (Jakarta: PT Rajagrafindo Persada, 2006)

Salim H.S. Contract Law, Theory, and Techniques of Contract Compilation. (Jakarta: Sinar Grafika, 2008)

Shared Research Inc. Anicom Holdings Research Coverage. (Tokyo: Shared Research Inc, 2016)

Subekti. Principles of Civil Law, Cet. XXVII. (Jakarta: Intermasa, 1995)

Taiyo and Daido Holdings. T\&D Annual Report 2018. (Tokyo: T\&D Holdings, 2018)

The In-House Lawyer, "Is Authorisation or A Licence Required and If So, How Long Does It Take on Average to Obtain Such Permission?" (2018) online: inhouselawyer 〈https://www.inhouselawyer.co.uk/wgd_question/is-authorisation -or-a-licencerequired-and-if-so-how-long-does-it-take-on-average-to-obtain-suchpermission/>

Tri Jata Ayu Pramesti, "Legal Responsibility of Caring for Animals" (2016) online: hukumonline.com 〈https://www.hukumonline.com/klinik/detail/ lt56e3ac03eel57 /tanggung-jawab-hukum-pemelihara-hewan-/\#_ftn2>

Wirjono Projodikoro. Azas-Azas Hukum Perdata, Cet. IX. (Bandung: Sumur Bandung, 1983)

World Animal Protection Organization, "France Animal Protection Profile" (2015) online: 〈http://api.worldanimalprotection.org/country/france〉

World Animal Protection Organization, "Japan Animal Protection Profile” (2015) online: worldanimalprotection.org 〈http://api.worldanimalprotection.org/country/japan〉 